\title{
RRAGC Gene
}

National Cancer Institute

\section{Source}

National Cancer Institute. RRAGC Gene. NCI Thesaurus. Code C142215.

This gene is involved in the localization of the mammalian target of rapamycin complex 1 (mTORC1). 